\title{
Use of Switchgrass as a Nursery Container Substrate
}

\author{
James E. Altland ${ }^{1,3}$ and Charles Krause ${ }^{2}$ \\ USDA-ARS, Application Technology Research Unit, Ohio Agricultural \\ Research and Development Center, 208 Ag. Eng. Building, 1680 Madison \\ Avenue, Wooster, OH 44691 \\ Additional index words. alternative substrate, potting mix, soilless medium, rose, Panicum \\ virgatum
}

\begin{abstract}
Loblolly pine (Pinus taeda L.) bark is the primary component of nursery container substrates in the eastern United States. Shortages in pine bark prompted investigation of alternative substrates. The objective of this research was to determine if ground switchgrass (Panicum virgatum L.) could be used for short production-cycle woody crops. Two experiments were conducted using 'Paprika' rose (Rosa L. 'ChewMayTime') potted in $15-\mathrm{cm}$ tall and wide containers. In Expt. 1, substrates were composed of coarse-milled switchgrass (processed in a hammermill with $1.25-$ and $2.5-\mathrm{cm}$ screens) amended with $0 \%, 30 \%$, or $50 \%$ peatmoss and fertilized with 100,250 , or $400 \mathrm{mg} \cdot \mathrm{L}^{-1}$ nitrogen $(\mathrm{N})$ from ammonium nitrate. In Expt. 2, substrates were composed of coarse-milled (similar to Expt. 1) or fine-milled switchgrass (processed through a single $0.48-\mathrm{cm}$ screen), amended with $0 \%$ or $30 \%$ peatmoss, and fertilized with the same $\mathrm{N}$ rates as in Expt. 1. Summarizing across both experiments, coarse switchgrass alone had high air space and low container capacity. Fine switchgrass had physical properties more consistent with what is considered normal for nursery container substrates. Switchgrass pH was generally high and poorly buffered against change. Fine switchgrass had higher pH than coarse switchgrass. Tissue analysis of rose grown in switchgrass substrate for 7 to 9 weeks revealed low to moderate levels of calcium and iron, but all other nutrients were within acceptable ranges. Despite varying substrate physical properties and pH levels, all roses at the conclusion of the experiment were of high quality. Switchgrass processed to an appropriate particle size and amended with typical nursery materials should provide a suitable substrate for short production-cycle woody crops.
\end{abstract}

Containerized nursery and greenhouse crops are grown almost exclusively in soilless substrates. Substrates for outdoor nursery crops are primarily composed of softwood bark amended to some extent with peatmoss, sand, pumice, perlite, compost, and/or various other minor materials. Softwood barks used by the nursery industry are regional and dependent on local forest inventories with most nurseries on the East Coast, Midwest, and southern United States using loblolly pine (Pinus taeda L.) bark (PB) and the West Coast using douglas fir [Pseudotsuga menziesii (Mirb.) Franco] bark. A decrease in forest products output, coupled with increased use of bark as a fuel at paper and lumber mills, has caused a decline in $\mathrm{PB}$ inventories available for horticultural use. Increasing demand for wood-based ethanol over the next 20 years will cause even greater

Received for publication 10 July 2009. Accepted for publication 25 Sept. 2009.

Special thanks to Erin Lowe and Leona Horst for their skillful technical assistance.

Mention of proprietary products or company is included for the reader's convenience and does not imply any endorsement or preferential treatment by USDA/ARS

${ }^{1}$ Research Horticulturist.

${ }^{2}$ Research Leader and Plant Pathologist.

${ }^{3}$ To whom reprint requests should be addressed; e-mail James.Altland@ARS.USDA.GOV. competition for $\mathrm{PB}$ and other woody biomasses (Day, 2009).

Scientists have explored replacements for $\mathrm{PB}$ in nursery containers. Researchers at Auburn University are exploring the use of a product called clean chip residual for nursery crops (Boyer et al., 2009). Researchers in Mississippi and Alabama are exploring the concept of using a WholeTree ${ }^{\mathrm{TM}}$ product, which involves harvesting whole trees, grinding them to an appropriate particle size, and using this as a bark substitute (Fain et al., 2008). Researchers in Virginia have used a similar approach in exploring the possibility of wood fiber sawdust for production of containerized nursery crops (Jackson et al., 2006; Wright and Browder, 2005; Wright et al., 2008). To summarize all this research, use of pine wood materials, as opposed to bark only, provides a suitable environment for plant growth with respect to substrate physical and chemical properties. This approach is proving successful in the southeastern United States where pine plantations, paper mills, and lumber mills are primarily located. This approach would be difficult to adopt in the northeastern and midwestern United States where there is less forestry activity and fewer softwood forest plantations (Lu et al., 2006).

Switchgrass (Panicum virgatum L.) is a native grass grown throughout the United States for its biofuel potential. Because it can be grown in upper Midwest states that have abundant farmland, and because it offers high biomass yields, it has potential for replacing pine bark as the primary potting component in nursery containers. Others have attempted to grow container plants in substrates comprised of grass clippings. Kresten Jensen et al. (2001) reported that English ivy (Hedera helix L.) grew well in composted miscanthus (Miscanthus ogiformis) substrates, although dry matter accumulation was greater in peat-based substrates. Dresboll and Thorup-Kristensen (2005) assessed the suitability of miscanthus clippings for use as a container substrate by measuring various physical properties of this material and other composted crop residues. Their (Dresboll and Thorup-Kristensen, 2005) research did not include plant evaluations and their findings were generally inconclusive; however, they did document differences among wheat straw, hemp straw, and miscanthus straw with respect to waterholding capacity and moisture characteristic curves. Our objective was to document the suitability of locally grown switchgrass as the primary component in container nursery substrates with a short production-cycle woody crop.

\section{Materials and Methods}

Expt. 1. Baled switchgrass was obtained from a farm in Crawford County, PA. Switchgrass was grown and allowed to dry in the field before baling in early spring. Bales were processed in a tub grinder that included a hammermill with $1.25-$ and $2.5-\mathrm{cm}$ screens (H-1100 Haybuster II; Duratech Ind., Jamestown, ND). Hereafter, switchgrass ground with this machine is referred to as coarse switchgrass. Particle size distribution (Table 1) was determined by passing $\approx 100 \mathrm{~cm}^{3}$ oven-dried coarse switchgrass $\left(60{ }^{\circ} \mathrm{C}\right)$ through 19.0-, 12.5-, 6.30-, 4.0-, $2.8-, 2.0-, 1.4-, 1.0-, 0.71-, 0.50-, 0.35-$, $0.25-, 0.18-$, and $0.11-\mathrm{mm}$ soil sieves. Particles $0.11 \mathrm{~mm}$ or less were collected in a pan. Sieves and pan were shaken for 3 min with a RX-29/30 Ro-Tap ${ }^{\circledR}$ test sieve shaker (278 oscillations/min, 150 taps/min; W.S. Tyler, Mentor, $\mathrm{OH})$.

Treatment design was a $3 \times 3$ factorial with three substrates and three nitrogen (N) fertilizer rates. The three substrates included coarse switchgrass amended with $0 \%$, $30 \%$, or $50 \%$ sphagnum peatmoss $(\mathrm{v} / \mathrm{v})$. All substrates were amended with $0.9 \mathrm{~kg} \cdot \mathrm{m}^{-3}$ Micromax (The Scotts Co., Marysville, $\mathrm{OH}$ ) micronutrients and $1.2 \mathrm{~kg} \cdot \mathrm{m}^{-3}$ gypsum. Containers $(15 \mathrm{~cm}$ i.d.) were filled with substrate and planted with Oso Easy ${ }^{\mathrm{TM}}$ Paprika roses (Rosa 'ChewMayTime') that were $\approx 10 \mathrm{~cm}$ tall and $15 \mathrm{~cm}$ wide at the time of planting. Plants were potted 28 Oct. 2008 and placed in a glass greenhouse supplemented with sodium vapor lights providing $13 \mathrm{~h}$ of lighting from $0600 \mathrm{HR}$ to $1900 \mathrm{HR}$. Thermostat heat and cool points were set at 18 and $24{ }^{\circ} \mathrm{C}$, respectively. Fertilizer treatments were initiated on 30 Oct. 2008 and is designated as the 
experiment starting date. Plants were fertigated with 100,250 , or $400 \mathrm{mg} \cdot \mathrm{L}^{-1} \mathrm{~N}$ from ammonium nitrate $\left(\mathrm{NH}_{4} \mathrm{NO}_{3}\right)$ and $90 \mathrm{mg} \cdot \mathrm{L}^{-1}$ phosphorous $(\mathrm{P})$ and $225 \mathrm{mg} \cdot \mathrm{L}^{-1}$ potassium (K) from dibasic potassium phosphate $\left(\mathrm{K}_{2} \mathrm{HPO}_{4}\right)$. Plants were fertigated $4 \mathrm{~d}$ each week (Monday, Tuesday, Thursday, and Friday) and watered with tap water the remaining days. Fertigation and irrigation volume were adjusted to maintain $\approx 30 \%$ leaching fraction.

Substrate physical properties were determined before the experiment by packing in $347-\mathrm{cm}^{3}$ aluminum cores $(7.6 \mathrm{~cm}$ tall $\times 7.6$ $\mathrm{cm}$ i.d.) according to methods described by Fonteno and Bilderback (1993). There were three replications for each substrate. Aluminum cores were attached to North Carolina State University Porometers ${ }^{\mathrm{TM}}$ (Horticultural Substrates Laboratory, North Carolina State University, Raleigh, NC) for determination of air space (AS). Cores were weighed, ovendried for $4 \mathrm{~d}$ at $72{ }^{\circ} \mathrm{C}$, and weighed again to determine container capacity (CC). Total porosity (TP) was calculated as the sum of AS and CC. Bulk density $\left(\mathrm{D}_{\mathrm{b}}\right)$ was determined using oven-dried $\left(72{ }^{\circ} \mathrm{C}\right)$ substrate in the same $347-\mathrm{cm}^{3}$ cores. Substrate $\mathrm{pH}$ was measured using the pourthrough procedure at 2, 4, 6, and 9 weeks after treatment

Table 1. Switchgrass (Panicum virgatum) particle size distribution for coarse switchgrass processed through a hammermill equipped with 1.25 - and $2.54-\mathrm{cm}$ screens and fine switchgrass processed through a smaller hammermill with a single $0.47-\mathrm{cm}$ screen $(n=3)$.

\begin{tabular}{lccc}
\hline \multirow{2}{*}{$\begin{array}{l}\text { Screen } \\
\text { size }(\mathrm{mm})\end{array}$} & $\begin{array}{c}\text { Expt. 1 } \\
\text { Coarse (\%) }\end{array}$ & \multicolumn{2}{c}{ Expt. 2 } \\
\cline { 3 - 4 } Coarse (\%) & Fine (\%) \\
\hline Pan & 0.7 & 0.3 & 0.8 \\
0.106 & 1.0 & 0.6 & 1.2 \\
0.25 & 1.4 & 0.9 & 1.8 \\
0.35 & 3.2 & 2.0 & 4.4 \\
0.5 & 5.8 & 3.9 & 6.6 \\
0.71 & 10.6 & 8.8 & 10.5 \\
1.0 & 12.9 & 10.8 & 11.6 \\
1.4 & 16.4 & 17.2 & 15.2 \\
2.0 & 25.4 & 25.9 & 19.1 \\
2.8 & 14.6 & 17.4 & 9.7 \\
4.0 & 5.8 & 8.8 & 7.7 \\
6.3 & 1.6 & 2.7 & 8.3 \\
12.5 & 0.4 & 0.8 & 3.1 \\
\hline
\end{tabular}

initiation (WAT). Foliar samples were harvested (Mills and Jones, 1996) by first rinsing with deionized water and then drying at $72{ }^{\circ} \mathrm{C}$ for $3 \mathrm{~d}$. Samples were ground in a Tecator Cyclotec mill (Tecator AB, Hogenas, Sweden) through a $0.5-\mathrm{mm}$ screen. Foliar $\mathrm{N}$ was determined with a Vario Max $\mathrm{CN}$ analyzer (Elementar Americas, Mt. Laurel, NJ). Other macronutrients and micronutrients were determined with a Thermo Iris Intrepid ICPOES (Thermo Fisher Scientific, Waltham, MA). Shoot dry weight (SDW) and root dry weight (RDW) were determined at the conclusion of the study ( 9 WAT) by harvesting roots and shoots separately, rinsing them free of substrate, and oven drying them at $72{ }^{\circ} \mathrm{C}$ for $3 \mathrm{~d}$.

Expt. 2. Coarse switchgrass described in Expt. 1 was used again. In addition, a fine switchgrass material was generated by passing dried and baled switchgrass (same source material as Expt. 1) through a smaller hammermill (No. 30 with blower discharge; The C. S. Bell Co., Tiffin, $\mathrm{OH}$ ) equipped with a single $0.48-\mathrm{cm}$ screen. Particle size distribution for each material was determined as in Expt. 1 (Table 1).

Treatment design was a $2 \times 2 \times 3$ factorial with two switchgrass grades (fine and coarse), two peat amendment rates $(0 \%$ and $30 \%$ ), and three $\mathrm{N}$ rates, the same as those used in Expt. 1. Substrates were amended and irrigated similar as those in Expt. 1. The same rose cultivar and containers were used, and greenhouse conditions with respect to light and temperature were the same. Plants were potted 30 Jan. 2009. Substrate physical properties were determined as described in Expt. 1. Substrate $\mathrm{pH}$ was measured using the pourthrough procedure at 2, 4, and $7 \mathrm{WAT}$. Foliar nutrition, RDW, and SDW were determined at the conclusion of the experiment, 7 WAT.

In both experiments, there were six single plant replications per treatment combination arranged in a completely randomized design. Data were subjected to analysis of variance (ANOVA) and repeated measures ANOVA where data were measured more than once over time. Linear or quadratic trends over $\mathrm{N}$ rate were determined with orthogonal contrasts. Least significant difference (LSD) values for each parameter were calculated with Fisher's LSD test.

\section{Results and Discussion}

Physical properties. Physical properties of the three substrates differed with respect to AS and CC are shown in Table 2. Air space decreased from $53 \%$ to $36 \%$ with increasing peatmoss volume. Ideal AS levels are thought to be $10 \%$ to $30 \%$ (Yeager et al., 2007). By this standard, coarse switchgrass alone has extremely high AS, whereas that amended with $50 \%$ peatmoss is close to the ideal range. The ideal range for CC is thought to be $45 \%$ to $65 \%$ (Yeager et al., 2007); thus, the substrate containing only switchgrass would have less than ideal CC, whereas the other two substrates are within acceptable ranges. Although the substrate containing 70\% switchgrass has significantly lower TP than the other two substrates, a difference of $2 \%$ is inconsequential. Bulk density of the substrate containing $100 \%$ switchgrass was lower than with the other two substrates, but a difference of just $0.003 \mathrm{~g} \cdot \mathrm{cm}^{-3}$ is likely inconsequential.

In Expt. 2, physical property values of coarse switchgrass substrate were similar to those found in Expt. 1 when amended with $0 \%$ or $30 \%$ peatmoss. In Expt. $2, \mathrm{AS}, \mathrm{CC}, \mathrm{TP}$, and $\mathrm{D}_{\mathrm{b}}$ were affected by interactions between switchgrass grade and peatmoss amendment (Table 2). Peatmoss amendment decreased AS and increased CC in coarse switchgrass but had no effect on fine switchgrass. Regardless of peatmoss amendment, fine switchgrass had less AS and greater CC than coarse switchgrass. Bulk density of fine switchgrass was greater than coarse switchgrass, likely as a result of the finer particles that compress more efficiently in a given unit volume. Compared with the aforementioned recommended ranges for physical properties, fine switchgrass with or without peatmoss had closer to ideal physical properties than coarse switchgrass.

Substrate $p H$. In Expt. 1, repeated measures analysis indicated that $\mathrm{pH}$ was affected by an interaction among date, substrate type, and $\mathrm{N}$ rate $(P=0.0001)$. At $2 \mathrm{WAT}, \mathrm{pH}$ in substrates containing $100 \%$ switchgrass responded quadratically to increasing $\mathrm{N}$ rate, although differences among $\mathrm{N}$ rate treatments were minor and averaged 6.4 (Table 3). Amending substrates with $30 \%$ or $50 \%$ peatmoss reduced $\mathrm{pH}$ to 4.1 and 3.9 , respectively, averaged across $\mathrm{N}$ rate. Substrates amended

Table 2. Physical properties of switchgrass (SG) (Panicum virgatum) substrates amended with $0 \%, 30 \%$, or $50 \%$ peatmoss. $^{\text {. }}$

\begin{tabular}{|c|c|c|c|c|c|c|c|c|c|}
\hline \multirow[b]{2}{*}{$\begin{array}{l}\text { Switchgrass } \\
\text { grade }\end{array}$} & \multirow[b]{2}{*}{ Peat $(\%)$} & \multicolumn{4}{|c|}{ Expt. 1} & \multicolumn{4}{|c|}{ Expt. 2} \\
\hline & & Air Space $(\%)$ & $\begin{array}{c}\text { Container } \\
\text { capacity (\%) }\end{array}$ & $\begin{array}{c}\text { Total porosity } \\
(\%)\end{array}$ & $\begin{array}{c}\text { Bulk density } \\
\left(\mathrm{g} \cdot \mathrm{cm}^{-3}\right)\end{array}$ & Air space $(\%)$ & $\begin{array}{c}\text { Container } \\
\text { capacity }(\%)\end{array}$ & $\begin{array}{c}\text { Total } \\
\text { porosity }(\%)\end{array}$ & $\begin{array}{c}\text { Bulk density } \\
\left(\mathrm{g} \cdot \mathrm{cm}^{-3}\right)\end{array}$ \\
\hline \multirow[t]{2}{*}{ Coarse } & 0 & $53 \mathrm{a}^{\mathrm{y}}$ & $36 \mathrm{c}$ & $89 a$ & $0.068 \mathrm{~b}$ & $55 \mathrm{a}$ & $29 \mathrm{c}$ & $84 \mathrm{~b}$ & $0.066 \mathrm{c}$ \\
\hline & 50 & $36 \mathrm{c}$ & $53 \mathrm{a}$ & $89 a$ & $0.072 \mathrm{a}$ & & & & \\
\hline \multirow[t]{2}{*}{ Fine } & 0 & & & & & $37 \mathrm{c}$ & $53 \mathrm{a}$ & $90 \mathrm{a}$ & $0.092 \mathrm{a}$ \\
\hline & 30 & & & & & $37 \mathrm{c}$ & $52 \mathrm{a}$ & $90 \mathrm{a}$ & $0.089 \mathrm{a}$ \\
\hline Main effects & & & & & & \multicolumn{4}{|c|}{ Significance } \\
\hline Interaction & & & & & & 0.0382 & 0.0009 & 0.0028 & 0.0008 \\
\hline
\end{tabular}

${ }^{\mathrm{z}}$ Switchgrass used was classified as either coarse (processed through 1.25- to 2.5-cm screens) or fine (processed through a $0.47-\mathrm{cm}$ screen) $(\mathrm{n}=6$ ).

${ }^{y}$ Means with different letters, within a column, are significantly different according to Fisher's protected least significant difference test. 
with $30 \%$ peatmoss also responded quadratically to increasing $\mathrm{N}$ rate, whereas those amended with $50 \%$ peatmoss did not. By 9 WAT, substrates containing either $0 \%$ or $30 \%$ peatmoss were again affected by $\mathrm{N}$ rate with $\mathrm{pH}$ decreasing linearly with increasing $\mathrm{N}$ rate. Similar to results at 2 WAT, substrates containing only $50 \%$ switchgrass were unaffected by $\mathrm{N}$ rate. Averaging across $\mathrm{N}$ rate, $\mathrm{pH}$ for substrates containing $0 \%, 30 \%$, or $50 \%$ peatmoss were 5.9, 4.6, and 3.9, respectively, and each differed significantly from the others (contrast analyses, $P \leq 0.01$ across all comparisons). Argo and Biernbaum (1996) reported that a water-soluble fertilizer containing $50 \% \mathrm{NH}_{4}{ }^{+}-\mathrm{N}$ reduced $\mathrm{pH}$ over time. The water-soluble fertilizer used in this experiment contained $50 \% \mathrm{NH}_{4}{ }^{+}-\mathrm{N}$ and had a similar effect on $\mathrm{pH}$. The depression in $\mathrm{pH}$ was $\mathrm{N}$ rate-responsive in the two substrates containing primarily switchgrass. Previous unpublished research by the author has shown that switchgrass is poorly buffered against changes in $\mathrm{pH}$ from other amendments or fertilizers.

In Expt. 2, substrate pH was affected by switchgrass grade, peat amendment, and $\mathrm{N}$ rate (Table 4). At 2 and 4 WAT, pH increased and then decreased with increasing $\mathrm{N}$ rate in substrates amended with $30 \%$ peat, but did not respond to $\mathrm{N}$ rate in nonamended switchgrass. By 9 WAT, all substrates responded either linearly or quadratically to increasing $\mathrm{N}$ rate. Averaging across peatmoss amendments and $\mathrm{N}$ rates, $\mathrm{pH}$ was higher in fine switchgrass than coarse switchgrass $(P=$ $0.0001)$. This observation is consistent with findings in other research with switchgrass by the authors (J.E. Altland, unpublished data) in that $\mathrm{pH}$ increases as the particle size of switchgrass is reduced. Similar to Expt. 1, peatmoss amendment reduced substrate $\mathrm{pH}$.

Foliar nutrient content. Peatmoss amendment rate and $\mathrm{N}$ rate interacted for all foliar elements analyzed (Table 5). There is no information on nutrient sufficiency ranges for landscape shrub roses; however, inferences can be made from sufficiency ranges developed for cut-flower hybrid tea roses (Mills and Jones, 1996). All nutrients with the exception of calcium and iron were within sufficiency ranges (1\% to $2 \%$ and 56 to 200 $\mathrm{mg} \cdot \mathrm{kg}^{-1}$, respectively) suggested for the nine cultivars listed by Mills and Jones (1996). Foliar $\mathrm{N}$ increased with increasing $\mathrm{N}$ rate with all three substrate types. Roses grown in substrates containing $30 \%$ peatmoss had higher foliar $\mathrm{N}$ than roses in substrates with $0 \%$ peatmoss and numerically greater (although not statistically greater) foliar $\mathrm{N}$ than substrates with $50 \%$ peatmoss. If switchgrass were immobilizing $\mathrm{N}$ within the substrate such that less $\mathrm{N}$ was available for uptake, one would expect foliar $\mathrm{N}$ to increase with increasing peat amendment rate. However, increasing peat volume from $30 \%$ to $50 \%$ did not increase foliar $\mathrm{N}$ and, in fact, caused a decrease when $250 \mathrm{mg} \cdot \mathrm{L}^{-1} \mathrm{~N}$ was applied. Differences in foliar $\mathrm{N}$ are thus likely the result of differences in available water among the three substrates tested. A similar trend was observed with foliar $\mathrm{P}$ and $\mathrm{K}$ where increasing $\mathrm{N}$ rate tended to cause an increase in foliar levels with substrates containing $30 \%$ peatmoss resulting in higher foliar

$\mathrm{P}$ and $\mathrm{K}$ than other substrates. Calcium, boron, iron, and silicon all tended to decrease with increasing $\mathrm{N}$ rate and increasing peat amendment rate, suggesting higher available

Table 3. Effect of peatmoss amendment and nitrogen $(\mathrm{N})$ rate on $\mathrm{pH}$ of switchgrass (Panicum virgatum) substrates over time and root and shoot dry weight of roses (Rosa 'ChewMay Time') growing in those substrates $(\mathrm{n}=6)$.

\begin{tabular}{|c|c|c|c|c|c|c|c|}
\hline \multirow[b]{2}{*}{ Peat (\%) } & \multirow{2}{*}{$\begin{array}{c}\mathrm{N} \text { rate } \\
\left(\mathrm{mg} \cdot \mathrm{L}^{-1}\right)\end{array}$} & \multicolumn{4}{|c|}{ Substate $\mathrm{pH}^{\mathrm{z}}$} & \multirow{2}{*}{$\begin{array}{c}\text { Shoot } \\
\text { dry wt (g) }\end{array}$} & \multirow{2}{*}{$\begin{array}{c}\text { Root } \\
\text { dry wt (g) }\end{array}$} \\
\hline & & $2 \mathrm{WAP}$ & 4 WAP & $6 \mathrm{WAP}$ & 9 WAP & & \\
\hline \multirow[t]{4}{*}{0} & 100 & 6.56 & 6.46 & 6.39 & 6.30 & 4.1 & 2.2 \\
\hline & 250 & 6.25 & 6.63 & 6.66 & 5.97 & 5.4 & 1.7 \\
\hline & 400 & 6.49 & 6.12 & 5.97 & 5.63 & 5.1 & 1.6 \\
\hline & & $\mathrm{Q}^{* * *}$ & $\mathrm{~L}^{* * *} \mathrm{Q} * * *$ & $\mathrm{~L}^{* *} \mathrm{Q}^{* * *}$ & $\mathrm{~L}^{* * *}$ & NS & NS \\
\hline \multirow[t]{4}{*}{30} & 100 & 4.42 & 4.65 & 4.76 & 5.00 & 5.6 & 1.9 \\
\hline & 250 & 3.96 & 4.58 & 4.69 & 4.74 & 6.6 & 1.8 \\
\hline & 400 & 4.00 & 3.88 & 4.17 & 3.82 & 5.3 & 1.4 \\
\hline & & $\mathrm{L}^{* * *} \mathrm{Q}^{* * *}$ & $\mathrm{~L}^{* * *} \mathrm{Q}^{* * *}$ & $\mathrm{~L}^{* * *}$ & $\mathrm{~L}^{* * *}$ & NS & NS \\
\hline \multirow[t]{4}{*}{50} & 100 & 3.92 & 4.36 & 4.32 & 4.14 & 4.5 & 1.7 \\
\hline & 250 & 3.98 & 3.82 & 3.86 & 3.79 & 4.7 & 1.2 \\
\hline & 400 & 3.92 & 3.86 & 3.87 & 3.76 & 4.9 & 1.3 \\
\hline & & NS & $\mathrm{L}^{* * *} \mathrm{Q} * * *$ & $\mathrm{~L}^{*} \mathrm{Q}^{*}$ & NS & NS & NS \\
\hline $\operatorname{LSD}_{0.05}$ & & 0.11 & 0.19 & 0.27 & 0.42 & 1.8 & 0.7 \\
\hline Main effects & & & & Signifi & nce & & \\
\hline Peat $(\mathrm{P})$ & & 0.0001 & 0.0001 & 0.0001 & 0.0001 & 0.0735 & 0.1048 \\
\hline $\mathrm{N}$ rate $(\mathrm{N})$ & & 0.0001 & 0.0001 & 0.0001 & 0.0001 & 0.2437 & 0.0383 \\
\hline $\mathrm{P} * \mathrm{~N}$ & & 0.0001 & 0.0001 & 0.0001 & 0.0001 & 0.6856 & 0.8005 \\
\hline
\end{tabular}

${ }^{\mathrm{z}}$ Substate $\mathrm{pH}$ was determined with the pourthrough method.

$\mathrm{L}, \mathrm{Q}$, and NS represent linear, quadratic, or nonsignificant rate response with respect to $\mathrm{N}$ rate.

$*, * *$, and $* * *$ represent significant effects with $P$ values less than or equal to $0.05,0.01$, or 0.001 , respectively.

LSD values are the least significant difference as determined by Fisher's least significant difference test. $\mathrm{WAP}=$ weeks after planting.

Table 4. Effect of coarse of fine switchgrass (Panicum virgatum) substrate amended with $0 \%$ or 30\% peatmoss and fertilized with three nitrogen $(\mathrm{N})$ rates on substrate $\mathrm{pH}$ and rose (Rosa 'ChewMayTime') root and shoot growth grown in those substrates $(n=6)$.

\begin{tabular}{|c|c|c|c|c|c|c|c|}
\hline \multirow{2}{*}{$\begin{array}{l}\text { Switchgrass } \\
\text { grade }^{\mathrm{y}}\end{array}$} & \multirow[b]{2}{*}{ Peat $(\%)$} & \multirow{2}{*}{$\begin{array}{c}\mathrm{N} \text { rate } \\
\left(\mathrm{mg} \cdot \mathrm{L}^{-1}\right)\end{array}$} & \multicolumn{3}{|c|}{ Substate $\mathrm{pH}^{\mathrm{z}}$} & \multirow{2}{*}{$\begin{array}{c}\text { Root dry } \\
\text { wt (g) }\end{array}$} & \multirow{2}{*}{$\begin{array}{c}\text { Shoot dry } \\
\text { wt (g) }\end{array}$} \\
\hline & & & $2 \mathrm{WAP}$ & 4 WAP & $7 \mathrm{WAP}$ & & \\
\hline \multirow[t]{8}{*}{ Coarse } & 0 & 100 & 6.64 & 6.86 & 6.69 & 2.7 & 5.0 \\
\hline & & 250 & 6.72 & 6.70 & 6.59 & 2.5 & 7.9 \\
\hline & & 400 & 6.50 & 6.81 & 5.98 & 2.0 & 9.0 \\
\hline & & & NS & NS & $\mathrm{L}^{* * *} \mathrm{Q} *$ & $\mathrm{~L}^{* * *}$ & $\mathrm{~L}^{* * *} \mathrm{Q} *$ \\
\hline & 30 & 100 & 4.58 & 4.80 & 5.09 & 1.8 & 3.9 \\
\hline & & 250 & 4.75 & 5.44 & 5.21 & 1.5 & 7.4 \\
\hline & & 400 & 4.22 & 4.74 & 4.83 & 1.8 & 9.0 \\
\hline & & & $\mathrm{Q}^{* *}$ & $\mathrm{Q}^{* * *}$ & $\mathrm{Q}^{*}$ & NS & $\mathrm{L}^{* * *}$ \\
\hline \multirow[t]{8}{*}{ Fine } & 0 & 100 & 6.89 & 6.95 & 6.83 & 1.9 & 3.2 \\
\hline & & 250 & 6.84 & 6.99 & 6.75 & 1.5 & 6.4 \\
\hline & & 400 & 6.81 & 6.91 & 6.47 & 1.3 & 9.1 \\
\hline & & & NS & NS & $\mathrm{L}^{* *}$ & $\mathrm{~L}^{* *}$ & $\mathrm{~L}^{* * *}$ \\
\hline & 30 & 100 & 5.28 & 5.68 & 5.94 & 2.0 & 4.1 \\
\hline & & 250 & 5.49 & 5.90 & 5.63 & 1.4 & 8.3 \\
\hline & & 400 & 5.33 & 5.42 & 5.19 & 1.3 & 8.2 \\
\hline & & & $\mathrm{Q}^{*}$ & $\mathrm{Q}^{* * *}$ & $\mathrm{~L}^{* * *}$ & $\mathrm{~L}^{* * *}$ & $\mathrm{~L} * * * \mathrm{Q} * * *$ \\
\hline LSD & & & 0.26 & 0.16 & 0.24 & 0.4 & 1.3 \\
\hline Main effects & & & & & Significe & & \\
\hline Switchgrass & & & 0.0001 & 0.0001 & 0.0001 & 0.0001 & 0.1299 \\
\hline Peat $(\mathrm{P})$ & & & 0.0001 & 0.0001 & 0.0001 & 0.0001 & 0.6463 \\
\hline $\mathrm{S} * \mathrm{P}$ & & & 0.0001 & 0.0001 & 0.006 & 0.0001 & 0.0593 \\
\hline $\mathrm{N}$ rate $(\mathrm{N})$ & & & 0.0027 & 0.0001 & 0.0001 & 0.0001 & 0.0001 \\
\hline $\mathrm{S}^{*} \mathrm{~N}$ & & & 0.0802 & 0.3863 & 0.2254 & 0.3456 & 0.5122 \\
\hline $\mathrm{P} * \mathrm{~N}$ & & & 0.2212 & 0.0001 & 0.9509 & 0.1181 & 0.2938 \\
\hline $\mathrm{S} * \mathrm{P} * \mathrm{~N}$ & & & 0.3988 & 0.0012 & 0.0032 & 0.0744 & 0.0077 \\
\hline
\end{tabular}

${ }^{\mathrm{z}}$ Substrate $\mathrm{pH}$ was determined with the pourthrough method.

${ }^{y}$ Coarse switchgrass was processed through a hammermill with $1.25-$ and $2.54-\mathrm{cm}$ screens, whereas fine switchgrass was processed through a hammermill with a single $0.48-\mathrm{cm}$ screen.

$\mathrm{L}, \mathrm{Q}$, and NS represent linear, quadratic, or nonsignifican rate response with respect to $\mathrm{N}$ rate.

$*, * *$, and *** represent significant effects with $P$ values less than or equal to $0.05,0.01$, or 0.001 , respectively.

LSD values are the least significant difference as determined by Fisher's least significant difference test. $\mathrm{WAP}=$ weeks after planting . 
Table 5. Foliar nutrient content of rose (Rosa 'ChewMayTime') grown in switchgrass (Panicum virgatum) and peatmoss substrates fertilized with one of three nitrogen $(\mathrm{N})$ rates. ${ }^{\mathrm{z}}$

\begin{tabular}{|c|c|c|c|c|c|c|c|c|c|c|c|c|c|c|}
\hline $\begin{array}{l}\text { Switchgrass } \\
\text { grade }\end{array}$ & $\begin{array}{l}\text { Peat } \\
(\%)\end{array}$ & $\begin{array}{l}\mathrm{N} \text { rate } \\
\left(\mathrm{mg} \cdot \mathrm{L}^{-1}\right)\end{array}$ & $\mathrm{N}$ & Phosphorus & Potassium & Calcium & Magnesium & Sulfur & Boron & Iron & Manganese & Copper & Zinc & Silicon \\
\hline \multirow[t]{6}{*}{ Coarse } & \multirow[t]{2}{*}{0} & 100 & 2.82 & 0.43 & 1.8 & 1.4 & 0.41 & 0.20 & 77.0 & 83.4 & 372.0 & 6.2 & 33.2 & 195.6 \\
\hline & & 250 & 3.84 & 0.65 & 2.3 & 1.1 & 0.36 & 0.34 & 51.4 & 67.9 & 294.2 & 10.2 & 45.6 & 156.0 \\
\hline & \multirow[t]{3}{*}{30} & 100 & 3.64 & 0.61 & 2.2 & 1.1 & 0.37 & 0.33 & 60.4 & 73.9 & 616.0 & 9.6 & 42.4 & 146.5 \\
\hline & & 250 & 4.14 & 0.81 & 2.3 & 1.0 & 0.40 & 0.34 & 63.5 & 70.4 & 675.1 & 10.8 & 49.5 & 136.1 \\
\hline & & 400 & 4.43 & 0.87 & 2.6 & 0.8 & 0.36 & 0.34 & 58.6 & 58.7 & 487.7 & 8.2 & 37.2 & 131.1 \\
\hline & 50 & 400 & 4.42 & 0.79 & 2.5 & 0.7 & 0.31 & 0.32 & 59.6 & 53.7 & 414.8 & 6.9 & 28.3 & 126.3 \\
\hline $\mathrm{LSD}_{0.05}$ & & & 0.27 & 0.14 & 0.4 & 0.2 & 0.05 & 0.05 & 13.9 & 21.1 & 102.8 & 1.7 & 8.2 & 19.1 \\
\hline Substrate & & & 0.0001 & 0.0004 & 0.0339 & 0.0001 & 0.0001 & 0.0126 & 0.1214 & 0.2392 & 0.0001 & 0.0565 & 0.0002 & 0.0001 \\
\hline $\mathrm{N}$ rate & & & 0.0001 & 0.0004 & 0.0070 & 0.0001 & 0.0135 & 0.0020 & 0.0123 & 0.0038 & 0.0022 & 0.0347 & 0.1124 & 0.0001 \\
\hline Substrate & & & 0.0084 & 0.0165 & 0.0453 & 0.0114 & 0.0041 & 0.0001 & 0.0541 & 0.0532 & 0.0001 & 0.0001 & 0.0001 & 0.0026 \\
\hline \multirow{2}{*}{ Coarse } & \multirow{2}{*}{30} & 250 & 2.79 & 0.49 & 2.3 & 0.9 & 0.30 & 0.29 & 31.4 & 74.2 & 337.7 & 8.3 & 31.0 & 118.7 \\
\hline & & 400 & 2.87 & 0.48 & 2.0 & 0.7 & 0.29 & 0.28 & 38.3 & 59.3 & 348.6 & 7.5 & 35.0 & 119.6 \\
\hline \multirow[t]{6}{*}{ Fine } & \multirow[t]{3}{*}{0} & 100 & 1.56 & 0.28 & 2.1 & 1.0 & 0.36 & 0.14 & 71.7 & 38.6 & 82.0 & 3.5 & 22.3 & 217.7 \\
\hline & & 250 & 2.58 & 0.51 & 2.5 & 1.0 & 0.33 & 0.27 & 46.3 & 44.7 & 151.2 & 4.0 & 21.8 & 143.0 \\
\hline & & 400 & 2.99 & 0.61 & 2.3 & 1.0 & 0.34 & 0.32 & 47.4 & 59.9 & 359.9 & 6.2 & 41.8 & 167.0 \\
\hline & \multirow[t]{4}{*}{30} & 100 & 1.70 & 0.33 & 2.1 & 1.1 & 0.34 & 0.19 & 63.8 & 17.0 & 393.8 & 4.2 & 18.2 & 153.2 \\
\hline & & 250 & 3.14 & 0.60 & 2.5 & 1.0 & 0.33 & 0.31 & 41.9 & 50.3 & 381.0 & 12.5 & 40.5 & 115.7 \\
\hline & & 400 & 4.10 & 0.58 & 2.1 & 0.7 & 0.28 & 0.30 & 44.2 & 62.7 & 407.3 & 6.8 & 40.2 & 133.3 \\
\hline $\operatorname{LSD}_{0.05}$ & & & 0.83 & 0.05 & 0.1 & 0.2 & 0.04 & 0.02 & 10.5 & 20.9 & 70.9 & 4.1 & 7.8 & 18.6 \\
\hline \multicolumn{3}{|l|}{ Main effects } & \multicolumn{12}{|c|}{ Significance } \\
\hline SG type $(\mathrm{T})$ & & & 0.1147 & 0.0001 & 0.0001 & 0.1080 & 0.2331 & 0.0048 & 0.5752 & 0.0070 & 0.0166 & 0.9480 & 0.1604 & 0.0487 \\
\hline Peat $(\mathrm{P})$ & & & 0.0434 & 0.0045 & 0.8581 & 0.0001 & 0.0001 & 0.0001 & 0.0001 & 0.5161 & 0.0001 & 0.0129 & 0.0001 & 0.0001 \\
\hline
\end{tabular}

${ }^{\mathrm{z}}$ Coarse switchgrass was processed through a hammermill equipped with 1.25 - and 2.54-cm screens, whereas fine switchgrass processed through a smaller hammermill with a single 0.47 -cm screen $(\mathrm{n}=6)$.

LSD values are the least significant difference as determined by Fisher's test.

concentrations of these nutrients in switchgrass than peatmoss. Foliar magnesium, sulfur, manganese, copper, and zinc all varied by treatments but either showed only minor differences or showed no identifiable trend with respect to $\mathrm{N}$ or peatmoss rates.

In Expt. 2, foliar $\mathrm{N}$ content in roses showed a significant response to peat amendment (Table 5) and $\mathrm{N}$ rate; all other main effects and interactions were not significant. Averaging across switchgrass grades and $\mathrm{N}$ rates, roses grown with no peat had $2.37 \%$ foliar $\mathrm{N}$, whereas roses grown in substrate amended with $30 \%$ peat had $2.72 \%$ foliar $\mathrm{N}$. Foliar $\mathrm{N}$ and $\mathrm{P}$ increased with increasing $\mathrm{N}$ rate. Across substrates, foliar $\mathrm{K}$ was greatest with roses fertilized with $250 \mathrm{mg} \cdot \mathrm{L}^{-1} \mathrm{~N}$. Similar to Expt. 1, calcium and iron were at or below reported sufficiency ranges for rose, whereas all other foliar nutrients were within sufficiency ranges.

Plant growth. Shoot growth was significantly affected by amendment with peatmoss, but not by $\mathrm{N}$ rate or its interaction with peatmoss (Table 3 ). Substrates with $0 \%$, $30 \%$, and $50 \%$ peatmoss resulted in roses with $4.9,5.6$, and $4.7 \mathrm{~g}$ dried shoot mass, respectively. Root growth was marginally affected by substrate type $(P=0.1048)$ with root growth decreasing from 1.8 to $1.4 \mathrm{~g}$ as peatmoss level increased from $0 \%$ to $50 \%$ of substrate volume. Nitrogen rate affected RDW with RDW decreasing from 1.9 to 1.5 $\mathrm{g}$ as $\mathrm{N}$ rate increased from 100 to $400 \mathrm{mg} \cdot \mathrm{L}^{-1}$.

In Expt. 2, root and shoot growth were affected by switchgrass grade, peat amendment, and $\mathrm{N}$ rate (Table 4). Root growth decreased linearly with increasing $\mathrm{N}$ rate. Root growth was greatest in substrates with coarse switchgrass and no peatmoss. In this experiment and others conducted by the senior author, root growth of roses appears to increase in response to decreasing waterholding capacity. Shoot growth increased linearly or quadratically with increasing $\mathrm{N}$ rate among all switchgrass grade and peatmoss combinations. Averaging across N rates, no substrate combination provided superior growth among those tested.

In summary, switchgrass can be processed and modified such that it is suitable for production of short-term woody crops such as landscape shrub roses. Physical properties of switchgrass substrates will depend on the degree to which it is ground and amended with peatmoss and other components. Container capacity of switchgrass seems primarily governed by its particle size distribution. In these experiments, switchgrass processed through a $0.47-\mathrm{cm}$ screen provided ideal physical properties, whereas switchgrass processed through a larger screen required amendment with $30 \%$ or $50 \%$ peatmoss to achieve the proper ratio of AS to CC. Processing with smaller screens will require more energy and higher production costs and thus will be an important consideration in development of switchgrass substrates.

Substrate $\mathrm{pH}$ of $100 \%$ switchgrass has been between 6.5 and 7.5 in this and other experiments by the senior author (J.E. Altland, unpublished data) with $\mathrm{pH}$ increasing as the proportion of fine particles increases. Although the various species of plants grown in nurseries respond differently to substrate $\mathrm{pH}$, the aforementioned range of switchgrass $\mathrm{pH}$ is higher than what is typically considered ideal. Furthermore, switchgrass seems poorly buffered against change from irrigation water or fertilizer amendment. Future research will 
evaluate amendment with composts with the intent of buffering against $\mathrm{pH}$ change.

Foliar nutrient content data suggest switchgrass provides a suitable medium for delivering plant nutrients through typical nursery fertilizer methods. Foliar calcium levels were low in some treatments. Because substrate $\mathrm{pH}$ is typically high, amendment with lime will not likely be needed. Lime amendments supply a large portion of calcium fertility; thus, some alternative calcium source (perhaps gypsum) will be explored. Foliar iron levels were similarly low, but this can also be remedied by amendment with iron sulfate.

Overall plant growth was vigorous in all treatments regardless of substrate type. Roses have been reported to grow over a wide range of $\mathrm{pH}$ (McCall, 1980) and are considered better suited to well-drained substrates (J. Lee, personal communication). Thus, it is not surprising that roses in this study grew well in substrates with $\mathrm{pH}$ ranging from 3.76 to 6.86 or in substrates with suboptimal $\mathrm{CC}$. Future experiments will evaluate amendments to lower and stabilize $\mathrm{pH}$, moderate physical properties, supplement additional calcium and iron, and document substrate conduciveness to root pathogens. A wider range of plant mate- rials with more specific requirements for $\mathrm{pH}$ and substrate water content will also be used.

\section{Literature Cited}

Argo, W.R. and J.A. Biernbaum. 1996. The effect of lime, irrigation-water source, and watersoluble fertilizer on root-zone $\mathrm{pH}$, electrical conductivity, and macronutrient management of container root media with impatiens. J. Amer. Soc. Hort. Sci. 121:442-452.

Boyer, C.R., C.H. Gilliam, G.B. Fain, T.V Gallagher, H.A. Torbert, and J.L. Sibley. 2009. Production of woody nursery crops in clean chip residual substrate. J. Environ. Hort. 27:56-62.

Day, M. 2009. Mulch producers tune into biofuel boom. Soil Mulch Producers News 3:1-3, 16.

Dresboll, D.B. and K. Thorup-Kristensen. 2005. Structural differences in wheat (Triticum aestivum), hemp (Cannabis sativa) and Miscanthus (Miscanthus ogiformis) affect the quality and stability of plant based compost. Scientia Hort. 107:81-89.

Fain, G.B., C.H. Gilliam, J.L. Sibley, and C.R Boyer. 2008. WholeTree substrates derived from three species of pine in production of annual vinca. HortTechnology 18:13-17.

Fonteno, W.C. and T.E. Bilderback. 1993. Impact of hydrogel on physical properties of coarsestructured horticultural substrates. J. Amer. Soc. Hort. Sci. 118:217-222.
Jackson, B.E., R.D. Wright, and J.F. Browder. 2006. Growth of Japanese holly in pine chips and pine bark as influenced by fertilizer rate. HortScience 41:1027 (Abstr.).

Kresten Jensen, H.E., M. Leth, and J.J. Lonsmann Iversen. 2001. Growth of Hedera helix L. container plants in compost substrates made with Miscanthus ogiformis Honda straw and various N-sources. Compost Sci. Util. 9:206214.

Lu, W., J. Sibley, C.H. Gilliam, J.S. Bannon, and Y. Zhang. 2006. Estimation of U.S. bark generation and implications for horticultural industries. J. Environ. Hort. 24:23-28.

McCall, W.W. 1980. Soil preparation for roses. Hawaii Cooperative Extension Publication. General Home Garden Series No. 25.

Mills, H.A. and J.B. Jones. 1996. Plant analysis handbook II. MicroMacro Publishing, Athens, GA.

Wright, R.D. and J.F. Browder. 2005. Chipped pine logs: A potential substrate for greenhouse and nursery crops. HortScience 40:1513-1515.

Wright, R.D., B.E. Jackson, J.F. Browder, and J.G. Latimer. 2008. Growth of chrysanthemum in a pine tree substrate requires additional fertilizer. HortTechnology 18:111-115.

Yeager, T.H., C.H. Gilliam, T.E. Bilderback, D.C Fare, A.X. Niemiera, and K.M. Tilt. 2007. Best management practices: Guide for producing nursery crops. Southern Nursery Assoc., Atlanta, GA. 